\title{
Approaching Difference, Inequality, and Intimacy in Tourism A View from Cuba
}

\author{
VALERIO SIMONI, Department of Anthropology and Sociology \& Global Migration \\ Centre, Graduate Institute of International and Development Studies, Chemin, Eugène-Rigot 2, \\ 1202 Geneva, Switzerland; Instituto Universitário de Lisboa (ISCTE-IUL), Centro em Rede \\ de Investigação em Antropologia, Lisbon, Portugal. Email: Valerio.simoni@graduateinstitute.ch
}

Based on ethnography of touristic encounters in Cuba, the article reflects on competing approaches to difference, inequality, and intimacy in tourism and in anthropology. Comparing the understandings of tourists and Cubans involved in these informal engagements, of the $\mathrm{Cu}$ ban authorities, and of scholars and commentators, three idealized scenarios and modes of interpretation are teased out. Rather than assessing their degree of accuracy or suggesting the primacy of one over the other, the article reflects on their co-presence and competing rationales, focusing on the conditions of their emergence and assessing their epistemological, moral, and political implications. In so doing, it foregrounds how the expectations, desires, and moral underpinnings that inform our findings and interpretative horizons resonate with those of the people we study, opening up different possibilities for estrangement and familiarization, and highlighting what is at stake in these processes both for anthropology and for those with whom we work.

Key words: difference, inequality, intimacy, tourism, interpretation, Cuba

This article reflects on competing approaches to difference, inequality, and intimacy in tourism and in anthropology, and how these approaches open up different possibilities for estrangement and familiarization with the people we visit and share experiences with, as tourists and as anthropologists. Based on ethnographic research on intimate touristic encounters in Cuba, it explores how the expectations, desires, and moral underpinnings that inform our findings and interpretative horizons resonate with those of the people we study, assessing the consequences that such convergences may have, and outlining possible ways forward for anthropological research on tourism and on North-South intimate encounters. In his reflections on fieldwork, tourism, and the ludic, Crick (1985) reflected on the possible, often uncomfortable similarities between tourists and ethnographers, and between tourism and anthropology. A decade earlier, MacCannell had already argued that his book The Tourist: A

Submitted March 12, 2017; accepted December 19, 2017; published online October 10, 2018. Journal of Anthropological Research (Winter 2018). (C) 2018 by The University of New Mexico. All rights reserved. 0091-7710/2018/7404-0006\$10.00 
New Theory of the Leisure Class "ought to be frightening to anthropologists" (1976:225), precisely for the similarities it uncovered between tourists and anthropologists. Since MacCannell's and Crick's publications, other scholars have debated the parallels between tourism and ethnography, and between tourism and anthropological theories and descriptions (Adams 2004; Bruner 1995; Crick 1995; Franklin 2003; Frohlick and Harrison 2008; Kaspin 1997; Michel 1998; Salazar 2013; Simoni and McCabe 2008). In a recent article addressing these issues, Salazar (2013) emphasizes for instance that outdated anthropological narratives and models, mainly from the first half of the twentieth century, still nourish exoticizing imaginaries and portraits of difference in many areas of the world. Old-school anthropology is thus recycled in tourism promotion to highlight difference and fix people in timeless customs and traditions. On a broader level, we may consider that both tourism and anthropology have contributed to interpreting, framing, and "taming" difference, rendering the strange more familiar. Of interest is uncovering how this is done, and what are the consequences of such processes.

Scholars debating similarities and differences between tourism and anthropology raise the question of what may distinguish an anthropological perspective from others, most notably from those of tourists. Here I pick up this question as a productive entry point to address, more broadly, anthropological approaches to difference, inequality, and intimacy; the ways familiarization and estrangement play out in such approaches; and the difference, if any, that an anthropological perspective can make. Most research exploring parallels between tourism and anthropology has dealt with issues of empirical field research and ethnography or with continuities in ways of portraying the Other. While taking stock of this scholarship, I wish to reflect on broader sensitivities and ways of knowing, and on approaches and interpretive frameworks that are used in making sense of the encounters that happen through tourism. Since the interest is in highlighting some general tendencies and convergences, the argumentation will not do justice to the subtler differences that may exist between scholars and does not provide a comprehensive review of the field. Accordingly, it is not individual studies and authors that are the object of this reflection and critique, but rather the broader approaches and modes of interpretation in which scholars participate, along with other actors involved in tourism. ${ }^{1}$

The findings presented here originate from my own research experience in Cuba, the difficulties I encountered when trying to make sense of what I was observing, and the ensuing effort to produce an anthropological perspective that could account for the different views, interpretations, and ideologies of tourists, of the Cuban authorities, and of my Cuban research participants, without simply privileging and adopting one of these views and interpretations in my analysis. Three main idealized scenarios will be considered in more detail, which alternatively portray Cuba and Cuban people (1) as virtuous victims spoiled by the neocolonial forces in tourism and their capitalist drive toward commoditization and exploitation; (2) as cunning, subversive tricksters, resisting and taking advantage of these same forces; or (3) as mimetic agents that embrace tourism and tourists in a claim for equal membership in a better, shared world. Rather than assessing the degree of accuracy of each of these scenarios, or suggesting the pri- 
macy of one over the other, the aim is to think through their co-presences and competing rationales, and to focus on the conditions of their emergence so as to uncover their epistemological, moral, and political implications.

The ethnographic material on which I base my reflections comes from 15 months of fieldwork carried out in Cuba between 2005 and 2016 in the city of Havana, the rural town of Viñales $(200 \mathrm{~km}$ west of the capital), and the beach resort of Santa Maria (in Playas del Este, thirty minutes' drive east of Havana), focusing on tourism and informal encounters between foreign visitors and Cuban men and women (Simoni 2016a). In these tourism settings, I observed and participated in interactions between tourists and Cubans and discussed with them the encounters and relationships they developed with each other.

\section{EXPLOITATION, COMMODITIZATION, AND THE LOCALS AS VICTIMS OF TOURISM}

When I met them on the beach in Santa Maria, Marcelo and his friends had barely spent a week in Cuba, traveling from Santiago de Cuba on the far east of the island toward Havana. ${ }^{2}$ In spite of its shortness, the journey of these Spanish men, most in their mid-twenties, had been very intense and led them to reflect on several key issues that were at the center of my research. Marcelo was studying sociology back in Spain, and he told me that during his travels he could not stop analyzing the situations he was confronted with. Discussing their relationships with Cuban people, and more particularly with Cuban women, this is what he had to say: ${ }^{3}$

In our group we are all men, so you can imagine. You see so many good-looking girls (chicas) [here in Cuba]; they seem to be taken out of a catalogue of models. But you know, when you go to a place, you already know that the ones that look at you are jineteras. ... ${ }^{4}$ You already know that — whichever relationship you will be able to establish—-there will be an implicit contractual relationship.

In the course of our conversation, Marcelo and his friends also employed the expression "ethical barrier" (barrera ética) when explaining why they did not engage in any sexual relationship with Cuban women, knowing that money would play a role. "If I am not going with prostitutes in Spain, why should I do it here? It's an ethical barrier," Marcelo argued. As we discussed the responsibility of tourists in bringing about these commoditized sexual relationships, he also made the following remarks:

Because, also, the ethical problem is not really here. The problem is in the First World, is with sex tourism. Because there are people who go to Thailand, Cuba, Brazil . . . and ninety percent, no let's say seventy percent of the people who come here come for that [for sex]. Therefore people here [Cubans], when they see you they think that's what we [tourists] all come for. People here got used to this, that tourists have this in their mind already. 
Elaborating on their refusal to engage in "sex tourism," Marcelo and his friends showed their determination not to lower their "ethical" standards and become accomplices of a commoditization of social relationships that they saw as driven by tourism, and grounded in socioeconomic asymmetries. Such a stance limited the scope of their interactions with Cuban women: all those coming toward them were deemed to be jineteras, desperate women who were interested in foreign men because of the money they had. In their narrative, tourism was therefore responsible for transforming Cuba into a place where needy local women became prostitutes in response to the tourists' demands.

Marcelo's remarks approximated the trope, very frequent in social science critiques of tourism in the 1970s and 1980s, of poor and marginal communities being impacted by the destructive external force of tourism and the invasive presence of affluent tourists, which irreversibly transformed and damaged the locality. As shown by Leite and Graburn (2009), this was a time of tourism social science research in which sexuality itself could be literally and metaphorically used "as a framework for articulating the exploitative aspects of tourism” (2009:41; see, e.g., Graburn 1983 and Britton 1982). Early social science work on tourism was inspired by critical analyses of the phenomenon that countered the prevailing economic approaches of the time, which tended to portray tourism as an ideal instrument for development (Leite and Graburn 2009). Reacting against these reductive assessments of tourism's positive potential, geographers, political scientists, sociologists, and anthropologists started highlighting the destructive effects tourism was having on poorer world regions, and the way it increased their dependency on richer, tourist-sending countries. Studies showed how tourism was better understood in continuity with historic patterns of colonialism and economic dependency, and that it could be approached as a form of imperialism or neocolonialism (Britton 1982; Nash 1978; Turner and Ash 1975). Among anthropologists, tourism was first approached in terms of "acculturation" (Nuñez 1963) to ascertain how the tourists' culture impacted that of the host society. The case that the influx of tourists would negatively impact local culture by commercializing it was clearly made by Greenwood (1978) in his analysis of the process of "cultural commoditization," which argued that tourism caused cultural degradation and a loss of meaning and authenticity.

Greenwood's arguments became very influential and informed the anthropological debates on tourism and its consequences. They still resonate with popular critiques articulated in the public sphere by tourism commentators and the protagonists of touristic encounters themselves, as the following examples taken from my fieldwork in Cuba illustrate. Among the tourists I met in Cuba, many criticized the commoditization of sexuality to which Marcelo and his friends referred, but to the contrary, they did not lose the hope of finding that kind of "genuine hotness" that also made Cuba's reputation abroad - the image of the sensual and "hot" Cuban as a valued cultural peculiarity and "strangeness" that tourism narratives helped apprehend and make more familiar (Simoni 2011, 2013). ${ }^{5}$ These were tourists who preferred 
to move outside the main tourism routes in order to access what we might call the "authentic" culture of intimacy and sexuality of Cuban people. A group of young Italians encountered during their annual one-month stay in Cuba liked, for instance, to spend the bulk of their holidays in the town of Las Tunas, on the eastern part of the island and several hours from Havana. This, as one of them put it, was a place "without any tourism attraction," the "real" Cuba, where you could still meet genuinely with $\mathrm{Cu}$ ban people, in a less commercialized atmosphere; have amazing parties; and easily find a "girlfriend" (novia) with whom to spend the holiday. Another young Italian man I briefly met in a disco recalled nostalgically how six or seven years earlier Cuban people were more ingenuous, more naive, whereas now, excluding some areas outside Havana, they were becoming more and more "like us," "money-oriented," and in the process of "capitalizing" (capitalizzare) themselves. Two opposing scenarios are articulated here: a positively valued (but almost vanished) local culture of fun-loving, sexually permissive "hot" Cubans, with whom one could genuinely relate, and the negative transformations for which tourism was responsible, more particularly its role in the commoditization of sexual relationships and the booming of prostitution. The solution for many tourists with whom I spoke was to get "off the beaten track" and jump into the picturesque frame of the still-"hot" Cuba. What we are dealing with here is one of the long-standing tropes of tourism, characterized by MacCannell (1976) as the quest for authenticity. In this case, what was sought after by tourists was the authentic "hot" Cuban (Simoni 2013).

A significant parallel can be traced here with the Cuban authorities' stance on tourism and their take on the phenomenon of tourism hustling, prostitution, and jineterismo - or one of their stances, that is, as these were also diverse, changeable, and not always consistent (see Berg 2004; Daigle 2015; Garcia 2010; Stout 2008). The critique of tourism-led prostitution made by Marcelo and his friends resonates in this case with the remarks of Fidel Castro in a 1999 speech, when the then-president blamed tourism and foreign men for "tricking, exploiting, corrupting, and filling [Cuban women] with vice," seen by him as victims in need of rehabilitation (Castro Ruz 1999, my translation from the Spanish original; see also Paternoso 2000 and Garcia 2010). The way Cuban authorities and institutions have responded to jineterismo is not monolithic, but among these responses we can detect a line of argument that portrays Cuban women engaging in sexual relations with foreign tourists as victims. In Castro's quote, they appear as victims of tourists; at other times they are seen, more broadly, as contaminated by capitalist values and modes of thinking that have infiltrated Cuba also as a result of tourism. For the vice-director of the Cuban Centre for the Study of Youth (Centro de Estudios Sobre la Juventud [CESJ]), for instance, "the influx of comparatively affluent tourists has created new 'necessities' for Cubans of all ages but especially young people who want to dress stylishly and carry the latest cell phones and music players, items that have become 'axes in the process of alienation' from the mainstream of Cuban society” (Daigle 2015:149). 
Taking action against the proliferation of such tourism-related "moral weakening" of Cuban citizens, the Federation of Cuban Women (Federación de Mujeres Cubanas $[\mathrm{FMC}])^{6}$ advocated state-sponsored programs to "stop young Cuban women from getting involved with tourist men" (Daigle 2015:164), part of an endeavor "to save those women who, having lost their way, have submitted to moral degradation" (FMC 2000, cited in Daigle 2015:164). Interviewed by Daigle (2015:166-74), a highlevel functionary with the FMC maintains that "no healthy relationship can exist between a Cuban woman and a foreign man" (Daigle 2015:168) given the economic differences that exist between them. Interpreting such stances, Daigle detects "nationalist fears of invasion and defilement by foreign influence" (2015:173). Her analysis converges with Alcázar's (2010:288) remarks on tourism in the early 1990s becoming a relatively easy target and scapegoat on which to blame the emergence of phenomenasuch as prostitution and the proliferation of illegal drugs - that contradicted the Cuban government's revolutionary ethic and threatened the supposedly unified moral fabric of the Cuban nation. Carter (2008) has a similar take on the matter and considers that in post-Soviet Cuba the tourist came to be seen as a "disease-ridden carrier that 'infects' Cuban citizens" (2008:252).

Notwithstanding their local specificities and anchorage in Cuban socialist ideological formations, it is important to situate these narratives in the broader context of tourism development in the 1990s, notably in countries in the Global South, and the kinds of analyses and public debates it generated. Making a noticeable entrance in the international tourism market after the fall of the Soviet Union in 1989, an event which prompted a dramatic economic crisis and led the revolutionary government to relaunch the tourism industry, ${ }^{7}$ Cuba also entered the regimes of value and moral critique associated with tourism. Its growing reputation as a pleasure destination and "sex tourism" paradise captured the attention of international media and scholars. The focus on the phenomenon of "touristic prostitution" in this Caribbean island finds parallels in other tourism destinations. As the works of Roux (2007, 2010) in Thailand and Salomon (2009) in Senegal have shown, the 1990s experienced increased media attention to "sex tourism" on an international scale, which led to a framing of this phenomenon as a new social problem, a dysfunction of society that called for moral and political action (Roux 2010:1).

All of the approaches considered above, whether from tourists, the authorities, or scholars, exemplify to some extent what we might call a "tourism impact" model, which in this case may be schematically equated with a view of Cuban people as relatively innocent, powerless, and negatively affected by the forces of tourism and the vices and corruption that the affluent and powerful tourists bring with them. ${ }^{8} \mathrm{Al}$ though the "impact" language and approach are still present in social science tourism research, they are no longer as dominant, and they have been convincingly criticized, particularly from the 1990s onward, for simplistically portaying local populations as fragile, cohesive entitites and passive recipients of tourism (Leite and Graburn 2009). Countering such assessments, and answering the early criticisms of authors such as 
Robert Wood, who in 1980 had already shown how the view of tourism as "spoiling" cultures betrayed "a Western ethnocentrism and romanticism in their desire to "preserve' cultures” (Wood 1980:564), a new wave of studies emphasized local people’s agency and active involvement in tourism; even the poorest and most marginalized populations were not passive targets, had agency, and acted tactically and strategically to make the most of tourism. This is another way in which my Cuban material can be read, but not without its own risks and potentially reductive simplifications, as I will now consider.

\section{LOCAL RESISTANCE, CUNNING TRICKSTERS, AND STRATEGIC INTIMACIES}

Whether in guidebooks' advice or in tips exchanged by tourists in Cuba, narratives of deceitful relationships with Cuban people and jineterismo have abounded since the booming of tourism in Cuba in the early 1990s, warning tourists of the eminently materialistic agendas of Cuban people (Simoni 2014). Among the research contexts in which jineterismo and mercentary intimacies were much talked about was Santa Maria's beach, a place frequented by many heterosexual men who came to Cuba year after year, lured by the prospect of sexual adventures with Cuban women. "You must be crazy to fall in love with a Cuban girl" was the frequent comment among these tourism "veterans." In this context, tourists who admitted "falling in love" with a $\mathrm{Cu}$ ban were easily scorned for their naivety and derided as beginners, as "suckers" who failed to understand how things really worked in Cuba. What was highly valued instead, in this milieu, were the tales of strategic, deceptive countermoves at the expense of jineteros and jineteras, narratives that highlighted the tourists' own cunning in coping with the alleged "typical Cuban trickery."

Relying on a very cynical view of tourist-Cuban relationships, several male tourists I met in Santa Maria argued that one had to rely on the "same weapons" Cubans used and play according to their rules, which were the rules of subterfuge, manipulation, and deception. Following this reasoning, the two teams in the game- the tourists and the locals - remained forever anchored in their own worlds and agendas, and it seemed ludicrous to think they would one day share more than short-lived moments of sex and intimacy. "Their family is one and one only [i.e., the Cuban community/nation]!" "You'll never be able to trust them!" Such were the assessments that emerged in these moments of tourist sociability and gossip. No matter how long you stayed with a Cuban partner, you would always remain a foreigner to them, and they would never come to treat you as they did their fellow nationals. Although the views of these tourists were rather extreme, my ethnography suggests that tourists in Cuba tended to be highly skeptical of long-term relationships with the locals. The specter of possible deception, contrived emotions, strategic love or marriage, and other deceitful machinations at their expense was often lurking in their minds.

These interpretations assumed a divide between Cubans' self-presentations to outsiders and their actual motivations and agendas, which were considered ineluctably 
strategic. This interpretive logic is extremely widespread in an increasingly globalized field of tourism discourse and critique. It can be linked to tourism's drive to reach into the most intimate realms of the places and lives that come into its path, and with the tourists' preoccupation with being deceived by "fake" touristic displays. MacCannell $(1973,1976)$ made such quests for the "real" and "authentic" Other the key tenet of his theorization of tourism as a modern phenomenon. Drawing on Goffman's "front" versus "back" distinction (1959), MacCannell argued that modern tourists were longing to "enter the back regions of the places they visited," regions "associated with intimacy of relations and authenticity of experiences" (1973:589). For him, this quest was ultimately doomed to failure given that "tourist settings are arranged to produce the impression that a back region has been entered even when this is not the case" (1973:589). As shown by my ethnographic material, the basic tenets of MacCannell's conceptualization seem to have gained much popular recognition and find a parallel in the practices and interpretive frameworks of tourists, notably the most cynical ones, who did not believe in the possibility of authentic relationships with Cuban people (even the backstage is fake!). Most tourists I met despised the idea of being cheated and deceived and were frequently puzzled about the "real" intentions and motivations of the Cubans with whom they were interacting. Here is where notions of tourism hustling and jineterismo could act as a key interpretative resource to "unmask" —in a rather tautological, self-fulfilling, and impossible-to-disprove way-the "secret" motivations of Cubans, considered inevitably materialistic, strategic, deceptive, and fake.

The tourists' skepticism toward the possibility of establishing a "genuine," longterm relationship with the locals, and the related assumption that Cubans would only deploy "true" intimacy with fellow nationals, resonates with a widespread approach to jineterismo by Cuban authorities and institutions (Daigle 2015; Stout 2008). We can think of the view, presented in the previous section, that "a true relationships cannot exist between a Cuban man and a foreign woman” (Daigle 2015:179). Although the portrayals of jineteras as victims addressed above (epitomized in Fidel Castro's 1999 quote) suggested a lack of agency on their part in the face of powerful tourists, the Cuban authorities frequently attributed to them a more active role and responsibility. As shown by Daigle (2015), representatives of the National Centre of Sexual Education (CENESEX) and the CESJ (see above) saw Cuban women engaging in commoditized sex with tourists as "morally responsible for their own objectification” (2015:156). We rejoin here another frequently quoted (and often misinterpreted; see Stout 2008) remark of Fidel Castro, in which he reacted, in 1992, to the growing international condemnation of "sex tourism" in Cuba, and which highlights the difference between pre-revolutionary prostitution (driven by starvation) and current jineterismo:

There are prostitutes, but prostitution is not allowed in our country. There are no women forced to sell themselves to a man, to a foreigner, to a tourist. Those who do so do it on their own, voluntarily and without any need for it. We can 
say that they are highly educated prostitutes and quite healthy, because we are the country with the lowest number of AIDS cases (cited in Stout 2008:736-37). ${ }^{9}$

Such remarks, as observed by Stout (2008), caused much controversy among analysts and commentators of jineterismo in Cuba, a key point of contention being the notion of "needs" and what comes to count as such. Whereas Cuban institutions tended to see jineterismo as a worrying sign of rising individualism, materialism, and consumerism, scholars outside Cuba criticized the Cuban authorities for misrecognizing legitimate needs - including "access to dollar-only spaces, such as restaurants, nightclubs, and stores" (Pope 2005, quoted in Stout 2008:733). ${ }^{10}$ The local semantics of jineterismo are also important to consider here because they tend to subvert the view of sex workers as powerless victims and instead portray Cuban jineteros/as as "riders," as shrewd "conquerors" mounting tourists and "whipping" money out of them (Palmié 2004:244). Although debates continue on the legitimacy of jineteros/as motives and whether they respond to "essential needs" or "superfluous desires," all these perspectives see jineterismo as an active, essentially economic endeavor.

In terms of how these views resonate with broader social science approaches to tourism, it is fruitful to consider critical perspectives that emphasize local resistance to global forces, and whose goal is to highlight local agency and strategizing in the face of affluent, but ultimately easily duped, tourists. In the field of tourism research, such approaches were often developed as a critique of the "impact model" and the view of local populations as passive targets of tourism. No, was the counterargument, they are not passive, but rather active manipulators of tourism and tourists. Notions of resistance and coping that highlight the agency and relative power of tourists' hosts and brokers can, for instance, be found in the writings of Boissevain (1996), Chambers (2000), Cheong and Miller (2000), and Maoz (2006), just to mention some influential examples, which clearly dispel any idea of the receiving population as an innocent and powerless target of tourism. Building on the more relational approach to power advocated by Foucault (1980), and by Cheong and Miller (2000) for tourism analysis, Maoz (2006) recasts tourists as targets of the hosts' shrewd entrepreneurialism and skillful staging and manipulation. The emphasis is here on the locals' sophisticated techniques, deception strategies, and clever "veiled resistance" to take advantage of tourists, in an approach that challenges "the binary picture of dominators and dominated" (Maoz 2006:235) and accounts for the "mutual suspicion" and "cynical exploitation" that can characterize touristic encounters (2006:235).

In the field of research on intimate and sexual relationships in tourism, debates on the relations of power, exploitation, and domination that tourism brings into play are ongoing. Reviewing scholarship on sex tourism, Herold et al. (2001) argue that "theoretical conceptualizations have generally been guided by one of two competing perspectives of sexuality with one group of researchers typically viewing prostitutes as sexual victims and another as empowered sexual actors" (2001:979). ${ }^{11}$ Several authors writing on local men in tourism destinations having intimate relations with 
wealthier tourist women have underscored the "entrepreneurial" qualities of their endeavors, and the way these men are able to instrumentalize love and sentiment to extract resources from their foreign partners and improve their living conditions (e.g., Brown 1992; Dahles and Bras 1999; Herold et al. 2001; Nyanzi et al. 2005; Phillips 2002). This literature draws attention to the modalities, tactics, and strategies through which foreign women are seduced, highlighting the competences and resourcefulness that men develop in engaging with tourists. Traversing these analyses is the notion that the men's seduction enterprise is essentially deceptive, guided by economic rationales, and manipulative of tourists.

While acknowledging the importance of this body of scholarship, and while I agree that there is agency among the recipients of tourism too, and that social scientists should take it into account, I think more attention needs to be devoted to clarifying the kind of agency we are referring to. This is to avoid falling into simplistic views that ascribe any "self-evident virtues" (Laidlaw 2002:315) to very vague notions of agency. As Laidlaw writes in his compelling critique of the ubiquitous uses of "agency" in contemporary social science research, this concept tends to be "preemptively selective" in that "we only mark them down as agency when people's choices seem to us to be the right ones" (2002:315). An easy mistake, for instance, is to make agency coincide with the model of rational economic action and with Western constructions of the person as a liberal, autonomous individual. ${ }^{12}$ Once again, what is at stake can be seen as "making the strange familiar," but doing it in too simplistic and ethnocentric a manner, relying on an aprioristic conception of what a person and their intentions and rationalities are, projecting our own taken-for-granted views onto those of the people we study.

Contrary to the tourists' cynical perspective I exemplified earlier, which despised Cubans' machinations at their expense, or to the Cuban authorities' critiques that saw jineteros/as' calculated endeavors as illegitimate, in scholarly approaches the hosts' strategies, entrepreneurialism, and cunning tend to be seen in a positive light. The overall approach to agency and to the hosts' (hidden) motives and agendas, however, bears similarities that need to be reflexively acknowledged and called into question. It is useful to consider here what Kelly (2012) sees as the pitfalls of "imagined identification," and its implications in terms of picturing other people's agency and ability to dissimulate. ${ }^{13}$ What happens in the case of the assessment of claims about torture in the British asylum process, on which Kelly grounds his reflections, is that "rather than turning people into passive objects, the process of trying to identify with those who have suffered can also lead to a sense of all too active agency among those who claim to have suffered" (2012:763). "The fiction of the 'rational man," continues Kelly, includes the recognition of "a capacity for dissimulation" and brings to the fore "the spectre of Homo economicus," which "always hangs behind that of Homo victimus" (2012:763). For Kelly, "the line between the incomprehension of assumed difference and the illusory understanding of enforced similarity . . . is faced by all attempts, including the anthropological, to understand the motivations, hopes, and desires of other people" (2012:766). 
In the case discussed here, the image of the cunning tourist broker who skillfully takes advantage of tourists has gained much interpretative purchase among foreigners visiting Cuba, but possibly also in those analyses of touristic encounters that wish to highlight the agency and resistance of the visited populations. What must be retained, building on Kelly's insights, is that critical reactions to the vision of host populations as powerless victims of tourism may end up producing a reverse imagefrom domination to resistance, from Homo victimus to Homo economicus - that makes it equally difficult for us to recognize alternative motives and drives in people's conduct. The risk we face here is to "romanticize resistance" (Abu-Lughod 1990; Piot 2010), idealizing in this case the image of cunning locals that, in spite of their subaltern position, are able to trick and deceive the structurally advantaged tourists—a category of people for which academics have traditionally displayed little sympathy (see Crick 1995). Going a step further, we may be easily tempted by the notion not only that the disadvantaged inhabitants of tourism destinations in the Global South are able to take advantage of tourists but that they should legitimately do so, and that we-as critical researchers sensitive to domination and ways of resisting it, and eager to highlight their economic agencies and rationalities — want and expect to see them do. The risk, therefore, is to move from the reductionism that sees hosts as victims to one that sees them primarily as resisting economic agents, and which, as I will now show, fails to account for other forms of agency and idealistic drives that can go beyond economic spheres of action and reasoning. This is when we need to recognize a third take on these intimate encounters, one that highlights its protagonists' ideals of, and aspirations for, "true," disinterested, long-term relationships.

\section{LOVE, MEMBERSHIP, AND RECOGNITION}

In spite of the widespread narratives of jineterismo and reciprocal trickery and deception as the norm and "fair play" in intimate tourist-Cuban relationships, other narratives and experiences also existed among the tourists I met in Cuba. After all, foreigners did engage in long-term relationships with Cubans, and some ended up marrying a Cuban partner. Even in the context of Santa Maria beach, where interlocutors tended to be averse to any sort of naive romanticism, I heard foreign men "admitting" —almost confessing out of other tourists' earshot- to being in love with a Cuban. In spite of diffuse skepticism, some kept alive the notion that love and romance could be found on the island, an island in which love itself, often in conjunction with sex and sensuality, has become a marketed tourism attraction (Simoni 2013).

My research devotes particular attention to how Cuban men voiced their ideals of true love and intimacy in their relationships with foreign tourist women, and what this meant for them beyond the ascription of an instrumental motive (Simoni 2014, 2015, 2016b). "European women are good; they only want love and sentiment" was said to me one night by my Cuban friend Aurelio. According to Aurelio, and his views were echoed by many other Cuban men with whom I engaged, Cuban women were nowadays interesadas, interested in what you had, in your money. Articulated 
here was the widespread critique, in post-Soviet Cuba, of the increased predominance of relaciones de interés ("relations for interest": i.e., materially motivated) as opposed to normal, "real" relationships and "true love" (Fosado 2005; Lundgren 2011; Stout 2014), a typical narrative of "moral decline, evidenced by materialist interests in romantic relationships" (Fernandez 2013:12) —and one that resonated with the institutional critiques of jineterisimo addressed above. The accusations of Cuban institutions and commentators who saw in jineterismo the embodiment of such decline were thereby deflected onto Cuban society as a whole, while portraying relations with tourists as a way out of such a predicament.

Discussing the issue further, Aurelio's friend Ernesto clarified that it was the fault of the system (es el sistema) in Cuba-that everything now was "por interés." ${ }^{14}$ Insofar as the Cuban context was judged responsible for "deforming" how things ought to be, "normally," we are confronted here with a discourse of exception, a "normative politics" (Povinelli 2006:208) that did not abandon the ideal of true love, but rather emplaced it elsewhere. For Aurelio and Ernesto such an ideal ought to inform people's practices under normal conditions, but since these conditions were lacking in Cuba, they were now looking at relationships with foreigners as a possible ground for its realization. Aurelio, Ernesto, and other Cubans I met similarly aspired to something more than a life dominated by economic needs and responsibilities, and they were also hoping for emotional fulfilment via true love and intimacy. In contrast to the bleak prospects they projected for relationships with fellow Cubans, said to be dominated by interés (self-interest), intimacy with foreign women appeared to be the realm in which true love was still possible.

Several of my Cuban friends expressed a desire and aspiration for a "normal life" abroad, for setting up family and raising kids with a foreign partner in Europe. As I have argued more extensively elsewhere (Simoni 2015, 2016b), such longing for "normalcy" 15 was signalled by the idioms of love people assumed would prevail in normal conditions of existence (Simoni 2016b), which they were willing to achieve. My interlocutors' aspirations could be read as a desire to get as close as possible "to the fantasy life of normativity" (Berlant 2011:167), a proximity that, in Berlant's words, "might be what remains to animate living on, for some on the contemporary economic bottom" (2011:167) —and most of the people I worked with did indeed express a feeling of being stuck on the bottom rung. Recent anthropological literature on intimacy discusses the diffusion of the romantic ideal of love across the world, showing how the ability to engage in "romantic," "selfless," "pure" love has become a hegemonic marker of modernization and of being an autonomous and self-determined subject (Povinelli 2006). ${ }^{16}$

The aspiration of being able to attain and live the fantasy of a "normal life" expressed by my Cuban interlocutors, one might argue, did nothing but reinforce that same hegemonic ideal, which has been criticized precisely for its universalist pretention and the way it discredits other forms of relationality as "inferior," "abnormal," or "retrograde." Although it may be true that my Cuban friends' ideals of love and normality 
reproduced hegemonic views, I want to go beyond this typically discourse-centerd line of interpretation, which can in fact act as another reductive device for "making the strange familiar." Another view is possible if we look for politics elsewhere, from another angle. I am inspired here by Piot's (2010) theoretical insights on new cultural imaginaries taking shape in contemporary West Africa, which move us away from "the romance of resistance" (2010:10) and encourage us to look for agency elsewhere, notably in "engagement with rather than rejection of Euro-otherness" (2010:10). In this view, the ideals of true love that guided my Cuban interlocutors can be seen as expressing a desire to overcome the limitations of life in Cuba and claim "membership" in a "global society" (Ferguson 2006) from which many of them felt excluded. Drawing on Piot, we could say that the Cuban men I worked with were trying to "embrace the future, through acts of mimetic engagement with that which they desire[d]" (Piot 2010:10) — a desire to be at one with, and share a common world with, their foreign partners.

What I think we should avoid here, in response to the rather utopian calls for love and friendship of my Cuban interlocutors, is replacing the interpretative reductions that saw Cubans as powerless victims or, at the opposite end, as powerful tricksters and deceivers with another reading that just saw them as complicit in the reproduction of hegemonic ideals of love and friendship. In other words, refrain from substituting a conceptual grid and interpretative closure with another totalizing understanding that is equally blind to, and not interested in, my interlocutors' calls for open-ended relational possibilities, their hopeful invitation to engage together, on an equal footing, in the construction of something shared. This shared reality was generated in tourism but aimed to go beyond it—beyond, but not toward the image of a supposedly "real" Cuba to be found "backstage," as dominant tourism narratives may have it; rather, toward something altogether new, something far-reaching that deeply engaged people's lives together.

In contrast to the approaches examined in the previous sections, which saw tourism "spoiling" Cubans (as victims) or, conversely, saw Cubans (as strategists) resisting and taking advantage of tourists, the perspective I highlight here acknowledges Cubans' drive to find new "avenues for living and being otherwise" (Daigle 2015:215), and to claim grounds of belonging that went beyond the Cuban society and nation. The first two approaches, despite their difference in apprehending Cubans' agency, seem to take for granted both that Cubans belong in Cuba and that their loyalties are (or ought to be) oriented toward their communities. The view of them as victims, and the correlated approach of tourism in terms of its negative impact, take as normative benchmark a cohesive Cuban community and nation to which Cuban citizens belong and contribute, and one that is best left untouched by foreign influence. By positing them as cunning strategists who instrumentalize tourists to their own advantage, the second perspective tends to imply that relations with foreign visitors are geared at benefitting one's (more) "real" life behind the scenes and fabrications of tourism, the "backstage" communitites where their "true(r)" intimacies (ought to) find expression. ${ }^{17}$ In both cases, what is left 
intact, taken for granted, and/or prescribed is the notion of a "local/national community" to which Cubans belong, and the idea that tourism and tourists are external entities and processes that are either disruptive of, or instrumentalized for, such communal/national life and ends. The third perspective examined here, by way of contrast, challenges any straightforward equation between community, nation, locality, belonging, and allegiance (see Gupta and Ferguson 1992). My Cuban interlocutors' drive to reach toward the tourists' world, and their association of "normality" with relations with foreign visitors and life outside Cuba, disrupt the ideal of a Cuban community (from family to nation) to which Cubans "naturally" (ought to) belong and owe allegiance.

Another important difference characterizing this third perspective needs to be underlined. Whereas the first two approaches consider tourist-Cuban relations predominantly in terms of the consequences they have on Cubans - the "negative impact"or as a means to something-the "instrumental" motive- the third perspective draws attention to the relationships themselves, encouraging us to recognize and take seriously the intrinsic meaning and value these may acquire for the protagonists. When analyzing Ernesto and Aurelio's claims, for instance, we need to account for the opposition they strived to maintain between their own "genuine" motives and the calculated, interesadas forms of relationality they criticized. To portray their longing for "true" love in intimate relations with tourists solely as being just another form of instrumentality, in this case a means to achieve a "normal" life abroad, notably by migrating with the help of their foreign partner, is to dismiss the intrinsic value they reclaimed for such relationships. ${ }^{18}$ By reading such engagements predominantly in terms of gains and losses, whether for tourists or for locals, the two perspectives considered in the previous sections risk devoiding such relationships of any autonomous significance and value. Our analytical gaze is automatically directed toward what "surrounds" them, toward what (over)determines (i.e., difference and inequality) and lies ahead (i.e., impact and consequences) of them. This makes it difficult to recognize and take seriously what happens "within" these relationships - their own generative potential, including the ways the protagonists involved, resisting their identification as either victims or jineteros/as, may recast their initial subject positions, downplaying difference and inequality, and striving to bring about other modes of being together. My call here is for our analyses to be able to move beyond limiting views of tourism as an external force that has either "impact" or is "used" for something, and to be ready to detect its profound entanglement in the lives and experiences of the people who meet through it.

\section{CONCLUSION}

In conclusion, it is useful to summarize the three main approaches I discussed in this article. I first considered the willingness to preserve and access an authentic Cuba unspoiled by tourism, with tourism seen mainly as a source of exploitation that commercializes difference, intimacy, and the Other. This kind of approach resonates with a widespread dislike for tourism and tourists, a dislike that has often been voiced by anthropologists (see Crick 1995), who for a long time saw in tourism and tourists 
an uglier reflection of themselves and their practices, with tourism exemplifying the superficial and exploitative relation with the Other that scholars wished to overcome and criticize. Scholarship that approaches tourism as a form of neocolonialism and imperialism has the merit of highlighting the broader structural inequalities into which tourism development becomes entangled, its historical continuities, and of not losing sight of who tends to have the upper hand in the encounters and relationships that tourism generates, and it finds useful refinements in contemporary political economy approaches to tourism (Bianchi 2015).

I then addressed a second approach in which the locals' agency is emphasized, particularly in its economic dimensions. Cubans are therefore seen as tricking and deceiving tourists, in a scenario with which many of us may be sympathetic, and which has become perhaps the most compelling one in contemporary social science analyses of tourism. Notions of local resistance to global forces and inequalities can easily support and reinforce this line of interpretation, which has the advantage of moving us beyond excessively schematic, top-down, and narrow views of domination and exploitation that leave little room for recognizing people's margins of maneuvering and agency. In spite of this, and no matter how seductive this approach may prove, I have shown that the image of the manipulative Cuban who tricks tourists via duplicity and dissimulation can also become a very reductive and limiting frame of interpretation. In the hands of some tourists, it acted as a self-fulfilling, tautological explanation to justify cynical and abusive behaviors at the expense of Cubans. For my Cuban research participants, being cast as cunning and always strategizing limited their longer-term prospects of intimate relationships with tourists, highlighting differences, maintaining divides, and reducing their attempts to create intimate connections to a form of emotional labor and tactical instrumentalization. For Cuban authorites and institutions, the inevitable equation of economic difference and interest (Daigle 2015:179) meant that no "real" relationships could ever exist between Cubans and tourists.

Caught in the oscillation between Homo victimus and Homo economicus (Kelly 2012), the first and second perspectives risk becoming two sides of the same interpretative coin, obstructing the recognition of other forms of agency and relationality. In this respect, a closer look at my research participants' future-oriented narratives and aspirations led me to recognize a third type of idealism, one that points toward a more mimetic engagement with tourists, which does not promote images of local resistance but shows instead the embracing of a more globalist orientation to the world, one that downplays difference and takes intimacy seriously as a pathway to reduce inequalities. We are thus confronted with Cubans' reluctance to embrace reductive interpretations of their engagements with tourists as inevitably cunning and instrumental, which obstructed their aspirations to be at one with the foreigners, to belong to the same social world. The language of love was the one chosen to evoke such relational possibilities and the serious commitment they implied. But beyond the reproduction of hegemonic ideals of romantic love, the claims of love and the invitations to love proffered 
by my Cuban research participants should also be read as pointing to a future yet to be scripted. What this third perspective also challenges us to do is to be ready to see beyond restrictive views of tourism "impacting" and "being used" by a "local community," approaches that risk reiterating the image of "communities," "cultures," and even "nations" as coherent and cohesive wholes to which people are expected to belong and feel allegiance to. The relations that happen in tourism may signal important shifts in taken-for-granted notions of belonging and should also encourage us to look more closely at what the experience of such relations - in and of themselves - is about. We can thus add to the well-established and no doubt legitimate focus on "impacts," "consequences," "uses," and "means" and also include in our analyses our interlocutors' emphasis on "doing" and "being" in a relationship.

It is indeed the impossibility of capturing these relationships using only one of the three approaches presented here that should also be retained at the end of this journey. All three approaches were at play in touristic Cuba, and all three may be put to use in scholarly conceptualizations of tourism. Our analyses can be strengthened by being reflexively aware of what each of them does, of what it is able to show, and what, on the contrary, it obscures or excessively reduces. The approaches examined here contrasted in the way they dealt with difference, inequality, and intimacy, but they also made sense in relation to each other. Each relied on specific conceptions of agency, intentionality, and power, and each enabled the emergence of certain subject formations and self-other relations, while obstructing others. Rather than simply replacing one approach with another, or having to establish which may be the best one, what seems important is to pay attention to their reciprocal conditions of emergence; to who is using them, when, and for which purpose; and to our responsibility and complicity, as social scientists studying these phenomena, in reproducing or criticizing one or the other. By paying attention to their purposeful deployments, competing rationales, and their epistemological, moral, and political implications, we can shed light on how our own interpretations resonate with those of the people we study, facilitating certain alliances while challenging others.

\section{NOTES}

The research for this article benefitted from the support of the Portuguese Foundation for Science and Technology (Postdoctoral Grant SFRH/BPD/66483/2009) and the Swiss National Science Foundation (Ambizione Fellowship, PZ00P1_147946). I wish to thank the guest editors of this special issue, Robin M. DeLugan and Patrick Naef; the editor of JAR, Lawrence G. Straus; and three anonymous reviewers for their useful comments and suggestions on earlier versions of this article. The reflections developed here were presented at the November 2015 American Anthropological Association annual meeting in Denver and at the Penser (avec et par) le tourisme seminar held at the University of Lausanne (Switzerland, October 2016), and I am grateful to the participants in these events for their insightful comments. The research on which the article is based would not have been possible without the generous collab- 
oration of the many Cuban and tourist men and women with whom I worked between 2005 and 2016, and my deepest gratitude goes to them. The article draws and expands on sections of the book Tourism and Informal Encounters in Cuba (Simoni 2016a).

1. In line with this rationale, the article also presents a rather selective view of the Cuban authorities' reactions to intimate encounters between foreign tourists and Cuban men and women. Such reactions have been shown to be diverse and changing, depending also on the Cuban institution at stake. I refer in particular to the work of Stout (2008) and Daigle (2015) for a thorough consideration of such differences and nuances.

2. All personal names are pseudonyms.

3. Quotes from research participants have been translated into English by the author and are based on recollections after the conversations took place.

4. From the Spanish for "rider" (jinete); in present-day Cuba the jineterola identification refers to the "riding of tourists" with cunning and for mercenary purposes and evokes notions of tourism hustling and, in this particular example, prostitution. As several scholars have underlined, jineterismo is a complex phenomenon that brings issues of morality, nation, race, class, and gender into play (see in particular the work of Alcázar 2009; Babb 2011; Berg 2004; Cabezas 2009; Daigle 2015; Fernandez 1999; Roland 2011), and which also evokes specific notions of agency and motive, as I consider more extensively in the next section.

5. Several authors examining the touristic image of Cuba have critically assessed the importance of sexual stereotypes, underscoring continuities with the slavery and colonial past of the island; e.g., Allen 2007; Babb 2011; Berg 2004; Cabezas 2004, 2006, 2009; Clancy 2002; Daigle 2015; Fusco 1997; De Sousa e Santos 2009; Fosado 2005; Garcia 2010; Hodge 2005; Kummels 2005; O’Connell Davidson 1996; Roland 2011; Sánchez Taylor 2000; Sierra Madero 2013; Stout 2008; Wonders and Michalowski 2001.

6. As explained by Stout (2008), "the Federation of Cuban Women is the statesponsored organisation established in August 1960 to foster women's participation in revolutionary goals" (2008:724). Among their most lauded efforts, relevant for the reflections here, was the campaign to eradicate prostitution undertaken in the early 1960s, which culminated in the 1965 official proclamation of the end of prostitution in the new socialist Cuba. As several scholars have noted, the FMC played a major role in the improvement of women's rights in Cuba, spearheading legislative projects for "universal child care, parental leave, equal pay for men and women" and "reproductive rights" (Daigle 2015:159).

7. The numbers of international tourists skyrocketed from 275,000 in 1989 to more than one million in 1996 (Figueras Pérez 2004:90; Quintana et al. 2005:113), reaching four million in 2016.

8. The response of Cuban authorities and institutions to the phenomenon of jineterismo shows an ambivalent approach to jineteros/as' agency and includes a stance that grants them much more autonomy and power than suggested here, as the next section will make clear. 
9. For a full translated transcript of Castro's speech, which was delivered at the evening session of the National Assembly of the People's Government, ANPP, at the Havana Convention Center on 11 July 1992, see http://lanic.utexas.edu/project/castro/db /1992/19920712.html.

10. Stout's analysis of competing readings of jineterismo warns us against erasing "ongoing local efforts at gender equity" when they do not "reflect neo-liberal feminist assumptions about 'freedom' and women's liberation” (2008:734). For Stout, the views of feminist scholars in the United States and Europe of "Cuban sex workers as perpetually marginalised dangerously equate agency with wealth and coercion with poverty," which she sees as "a common trope in studies of Third World prostitution" (Stout 2008:734). "The defence of a sex workers' right to pursue dollar-only spaces," continues Stout, "disassociates 'economics' and 'morality' as if need was an objective category devoid of political implications and cultural history" (2008:736). Note: "dollar-only spaces" refers here to those places that only accepted USD and, since 2004, the Cuban Convertible Currency [1 CUC = 1 USD]). The use of USD, legalized in Cuba in 1993, was officially banned in November 2004, when the CUC was introduced to counteract what Fidel Castro saw as a US attempt to obstruct the sending of dollars to Cuba (Brotherton 2008:268). International tourists traveling to Cuba are encouraged to convert foreign currency into CUC at government exchange centers [with a $10 \%$ surcharge on USD only] and may not participate in the Cuban peso (CUP) economy. Likewise, Cuban pesos, the currency in which most Cubans receive their salaries, cannot be used at certain "CUC-only" places (albeit an increasing number of establishments nowadays accept both currencies), such as hotels and restaurants targeting international visitors, or the widespread retail chain known as TRD, tienda de recaudación de divisas (store for the collection of foreign currency), popularly known as chopin (from "shopping").

11. We rejoin here the broader considerations of Constable (2009) in her review of scholarship on the commoditization of intimacy, and more particularly on approaches to trafficking and sex work, when she discusses the "agent-victim binary" and the way it "has proven to be a dead end of sorts" (2009:57). As Constable puts it: "Whereas certain feminist scholars and activists argue that all sex workers are victims, other scholars and feminists can respond with endless examples of agency and choice" (2009:57).

12. This is what the anlysis of Stout (2008) also alluded to, highlighting how competing feminist perspectives on jineterismo in Cuba could be grounded in different moral assumptions regarding "choice," "needs," and "economic motivation."

13. According to Kelly, "imagined identification is a necessary, though not sufficient, condition for compassion, sympathy, or empathy" (2012:754-55), which underpins such reasonings as "we know what pain is because we can all feel pain." Imagined identification leads to the recognition of mutual humanity, to compassion and sympathy, but it can also lead to doubt and suspicion of others and their intentions, particularly when we project our own views and intentionalities on them. 
14. I interpret Ernesto's critique of "el sistema" as referring to the overarching structural conditions of crisis, scarcity, and exeptionalism that, in the repeated conversations we had on the matter, he ascribed to Cuba post-1990. Although his critique included the Cuban government, which in his view was also responsible for the deplorable state in which the country found itself, his reference to "the system," which may be read as an allusion to Cuba's peculiar "political system," did not specifically single out the socialist aspect of the regime.

15. A fruitful parallel may be drawn here with Patico's (2009) reflections on "normalcy" when discussing how international matchmaking provides Russian women and American men a way to seek normalcy in their personal lives. In relation to the Cuban context, in her research on jineteras and their discourses of love for foreign tourists, de Sousa e Santos similarly quotes one of her informants as arguing that "people here want to have what is normal to have, simply what any person in the world can have [the world here representing Western countries]" (2009:422).

16. See in particular Cole and Thomas 2009; Faier 2007; Hirsch and Wardlow 2006; Hunter 2010; and Padilla et al. 2007.

17. We may note here that the authorities' critiques of jineterismo express concern precisely about the nature of such community, their ideal reference being the Cuban nation, a nation collectively and cohesively engaged in a socialist revolution. Accordingly, what is worrying is the way jineteros/as threaten the moral fabric of this ongoing national project.

18. A convergence can be uncovered here with Daigle's reflections (2015), when she argues that for Cuban women engaging in intimate relationships with foreign tourists, and who were discredited by the authorities as self-interested jineteras, these relationships could be "both means and ends" and "a goal in itself" (2015:156).

\section{REFERENCES CITED}

Abu-Lughod, L. 1990. The romance of resistance: Tracing transformations of power through Bedouin women, American Ethnolooist 17(1):41-55.

Adams, K. M. 2004. The genesis of touristic imagery: Politics and poetics in the creation of a remote Indonesian island destination. Tourist Studies 4(2):115-35.

Alcázar Campos, A. 2009. Turismo sexual, jineterismo, turismo de romance. Fronteras difusas en la interacción con el otro en Cuba. Gazeta de Antropología 25(1). Accessed 14 May 2012. http://hdl.handle.net/10481/6856.

- 2010. "La Cuba de verdad": Construcción de alteridades y turismo en la contemporaneidad. PhD dissertation, Universidad de Granada.

Allen, J. S. 2007. Means of desire's production: Male sex labor in Cuba. Identities: Global Studies in Culture and Power 14(1-2):183-202.

Babb, F. 2011. The tourism encounter: Fashioning Latin American nations and histories. Stanford, CA: Stanford University Press.

Berg, M. L. 2004. Tourism and the revolutionary New Man: The specter of jineterismo in late "Special Period" Cuba. Focaal: European Journal of Anthropology 43:46-56.

Berlant, L. 2011. Cruel optimism. Durham, NC: Duke University Press. 
Bianchi, R. 2015. "Toward a new political economy of global tourism revisited," in Tourism and development: Concepts and issues, second edition. Edited by R. Sharpley and D. J. Telfer, pp. 287-331. Bristol: Channel View.

Boissevain, J., ed. 1996. Coping with tourists: European reactions to mass tourism. Oxford: Berghahn Books.

Britton, S. G. 1982. The political economy of tourism in the Third World. Annals of Tourism Research 9(3):331-58.

Brotherton, S. 2008 "We have to think like capitalists but continue being socialists": Medicalized subjectivities, emergent capital, and socialist entrepreneurs in post-Soviet Cuba. American Ethnologist 35(2):259-74.

Brown, N. 1992. Beachboys as culture brokers in Bakau Town, The Gambia. Communitv Development Journal 27(4):361-70.

Bruner, E. M. 1995. “The ethnographer/tourist in Indonesia," in International tourism: Identity and chanoe. Edited by M.-F. Lanfant, I. B. Allcock, and E. M. Bruner, pp. 224-41. London: Sage.

Cabezas, A. L. 2004. Between love and money: Sex, tourism, and citizenship in Cuba and the Dominican Republic. Sions 29(4):984-1015.

2006. The eroticization of labor in Cuba's all-inclusive resorts: Performing race, class, and gender in the new tourist economy. Social Identities 12(5):507-21.

-2009. Economies of desire: Sex and tourism in Cuba and the Dominican Republic. Philadelphia: Temple University Press.

Carter, T. 2008. Of spectacular phantasmal desire: Tourism and the Cuban state's complicity in the commodification of its citizens. Leisure Studies 27(3):241-57.

Castro Ruz, F. 1999. Discurso del Presidente de la República de Cuba, Fidel Castro Ruz, en el acto por el aniversario 40 de la constitución de la Policía Nacional Revolucionaria, efectuado en el teatro "Carlos Marx, el día 5 de enero de 1999. Accessed 20 October 2016. http://www .cuba.cu/gobierno/discursos/1999/esp/f050199e.html.

Chambers, E. 2000. Native tours: The anthropology of travel and tourism. Long Grove, IL: Waveland Press.

Cheong, S.-M., and M. L. Miller. 2000. Power and tourism: A Foucauldian observation. Annals of Tourism Research 27(2):371-90.

Clancy, M. 2002. The globalization of sex tourism and Cuba: A commodity chains approach. Studies in Comparative International Development 36(4):63-88.

Cole, J., and L. Thomas, eds. 2009. Love in Africa. Chicago: Chicago University Press.

Constable, N. 2009. The commodification of intimacy: Marriage, sex, and reproductive labor. Annual Review of Anthropology 38:49-64.

Crick, M. 1985. "Tracing” the anthropological self: Quizzical reflections on field work, tourism, and the ludic. Social Analysis 17:71-92.

1995 "The anthropologist as tourist: An identity in question," in International tourism: Identity and chanoe. Edited by M.-F. Lanfant, I. B. Allcock, and E. M. Bruner, pp. 20522. London: Sage.

Daigle, M. 2015. From Cuba with love: Sex and money in the twenty-first century. Oakland: University of California Press.

Dahles, H., and K. Bras. 1999. Entrepreneurs in romance: Tourism in Indonesia. Annals of Tourism Research 26(2):267-93. 
De Sousa e Santos, D. 2009. Reading beyond the love lines: Examining Cuban jineteras' discourses of love for Europeans. Mobilities 4(3):407-26.

Faier, L. 2007. Filipina migrants in rural Japan and their professions of love. American Ethnologist 34(1): 148-62.

Federación de Mujeres Cubanas. 2000. Memoria del $7^{\circ}$ Congreso de la Federación de Mujeres Cubanas. Havana: FMC.

Ferguson, J. 2006. Global shadows: Africa in the Neoliberal World Order. Durham, NC: Duke University Press.

Fernandez, N. 1999. "Back to the future? Women, race, and tourism in Cuba" in Sun, sex, and gold: Tourism and sex work in the Caribbean. Edited by K. Kempadoo, pp. 81-89. Lanham, MD: Rowan and Littlefield.

- 2013. Moral boundaries and national borders: Cuban marriage migration to Denmark. Identities: Global Studies in Culture and Power 20(3):270-87.

Figueras Pérez, M. A. 2004. "El Turismo internacional y la formación de clusters productivos en la economía cubana," in Reflexiones sobre la economía cubana. Edited by O. E. Pérez Villanueva, pp. 85-99. La Habana: Editorial de Ciencias Sociales.

Fosado, G. 2005. "Gay sex tourism, ambiguity and transnational love in Havana," in Cuba transnational. Edited by D. J. Fernández, pp. 61-78. Gainesville: University Press of Florida.

Foucault, M. 1980. "Two lectures," in Power/knowledge: Selected interviews and other writings, 1972-1977. Edited by C. Gordon, pp. 78-108. New York: Pantheon.

Franklin, A. 2003. Tourism: An introduction. London: Sage.

Frohlick, S., and J. Harrison, eds. 2008. Engaging ethnography in tourist research. Tourist Studies 8(5), special issue.

Fusco, C. 1997. Jineteras en Cuba. Encuentro de la cultura cubana 4/5:52-64.

Garcia, A. 2010. Continuous moral economies: The state regulation of bodies and sex work in Cuba. Sexualities 13(2):171-96.

Goffman, E. 1959. The presentation of self in everyday life. Garden City, NY: Doubleday.

Graburn, N. 1983. Tourism and prostitution. Annals of Tourism Research 10(3):437-56.

Greenwood, D. J. 1978. "Culture by the pound: An anthropological perspective on tourism as cultural commoditization," in Hosts and guests: The anthropology of tourism. Edited by V. L. Smith, pp. 129-38. Oxford: Basil Blackwell.

Gupta, A., and J. Ferguson. 1992. Beyond "culture": Space, identity, and the politics of difference. Cultural Anthropoloog 7(1):6-23.

Herold, E., R. Garcia, and T. DeMoya. 2001. Female tourists and beach boys: Romance or sex tourism? Annals of Tourism Research 28(4):978-97.

Hirsch, J. S., and H. Wardlow, eds. 2006. Modern loves: The anthropology of romantic love and companionate marriage. Ann Arbor: University of Michigan Press.

Hodge, D. G. 2005. Sex workers of Havana: The lure of things. NACLA Report on the Americas 38(4):12-15.

Hunter, M. 2010. Love in the time of AIDS: Inequality, gender and rights in South Africa. Indianapolis: University of Indiana Press.

Kaspin, D. 1997. On ethnographic authority and the tourist trade: Anthropology in the house of mirrors. Anthropolooical Ouarterly 70(2):53-57.

Kelly, T. 2012. Sympathy and suspicion: Torture, asylum, and humanity. Lournal of the Roval Anthropolooical Institute 18(4):753-68. 
Kummels, I. 2005. Love in the time of diaspora: Global markets and local meaning in prostitution, marriage and womanhood in Cuba. Iberoamericana 5(20):7-26.

Laidlaw, J. 2002. For an anthropology of ethics and freedom. Lournal of the Roval Anthropolooical Institute 8(2):311-32.

Leite, N., and N. H. H. Graburn 2009. "Anthropological interventions in tourism studies," in The Sage handbook of tourism studies. Edited by T. Jamal and M. Robinson, pp. 35-64. London: Sage.

Lundgren, S. 2011. Heterosexual Havana: Ideals and hierarchies of gender and sexuality in contemporary Cuba. PhD dissertation, Uppsala University.

MacCannell, D. 1973. Staged authenticity: On arrangements of social space in tourist settings. American Journal of Socioloory 79(3):589-603.

. 1976. The tourist: A new theory of the leisure class. London: Macmillan.

Maoz, D. 2006. The mutual gaze. Annals of Tourism Research 33(1):221-39.

Michel, F. 1998. "Des manières d'être et de faire du touriste et de l'anthropologue," in Tourismes, touristes, sociétés. Edited by F. Michel, pp. 35-44. Paris: L'Harmattan.

Nash, D. 1978. "Tourism as a form of imperialism," in Hosts and guests: The anthropology of tourism. Edited by V. L. Smith, pp. 33-47. Oxford: Basil Blackwell.

Nuñez, T. 1963. Tourism, tradition, and acculturation: El weekendismo in Mexico. Ethnoloogy $2: 328-36$

O'Connell Davidson, J. 1996. Sex tourism in Cuba. Race \& Class 38(1):39-48.

Nyanzi, S., O. Rosenberg-Jallow, O. Bah, and S. Nyanzi. 2005. Bumsters, big black organs and old white gold: Embodied racial myths in sexual relationships of Gambian beach boys. Culture, Health and Sexuality 7(6):557-69.

Padilla, M., J. S. Hirsch, M. Munoz-Laboy, R. E. Sember, R. G. Parker, eds. 2007. Love and globalization: Transformations of intimacy in the contemporary world. Nashville, TN: Vanderbilt University Press.

Palmié, S. 2004. Fascinans or tremendum? Permutations of the state, the body, and the divine in late-twentieth-century Havana. New West Indian Guide 78(3/4):229-68.

Paternoso, S. 2000. Sexual revolution: Communism versus prostitution. The New Republic (10 July):18-22.

Patico, J. 2009. For love, money, or normalcy: Meanings of strategy and sentiment in the Russian-American matchmaking industry Ethnos 74(3):307-30.

Phillips, J. 2002. "The beach boys of Barbados: Post-colonial entrepreneurs," in Transnational prostitution: Changing global patterns. Edited by S. Thorbek and B. Pattanaik, pp. 42-45. New York: Zed Books.

Piot, C. 2010. Nostalgia for the future: West Africa after the Cold War. Chicago: Chicago University Press.

Pope, C. 2005. The political economy of desire: Geographies of female sex work in Havana, Cuba. Journal of International Women's Studies 6(2):99-118.

Povinelli, E. A. 2006. The empire of love: Toward a theory of intimacy, genealogy, and carnality. Durham, NC: Duke University Press.

Quintana, R. et al. 2005. Efectos y futuro del turismo en la economía cubana. La Habana: Instituto Nacional de Investigaciones Económicas.

Roland, L. K. 2011. Cuban color in tourism and La Lucha: An ethnography of racial meaning. New York: Oxford University Press. 
Roux, S. 2007. Importer pour exister: Empower et le "travail sexuel" en Thailande. Lien social et Politiques 58:145-54.

- 2010. Patpong, entre sexe et commerce. EspacesTemps.net. Accessed 3 April 2010. http://espacestemps.net/document8075.html.

Salazar, N. B. 2013. Imagineering otherness: Anthropological legacies in contemporary tourism. Anthropolooical Ouarterly 86(3): 669-696.

Salomon, C. 2009. Antiquaires et businessmen de la Petite Côte du Sénégal. Le commerce des illusions amoureuses. Cahiers d'études africaines 193/194(1-2):147-76.

Sánchez Taylor, J. 2000. "Tourism and 'embodied' commodities: Sex tourism in the Caribbean," in Tourism and Sex: Culture, Commerce and Coercion. Edited by S. Clift and S. Carter, pp. 41-53. London and New York: Pinter.

Sierra Madero, A. 2013. Cuerpos en venta: Pinguerismo y masculinidad negociada en la Cuba contemporánea. Nómadas 38:167-83.

Simoni, V. 2011. "L'interculturalité comme justification: Sexe 'couleur locale' dans la Cuba touristique," in Anthropologies de linterculturalité. Edited by A. Lavanchy, F. Dervin, and A. Gajardo, pp. 197-225. Paris: L'Harmattan.

2013. Intimate stereotypes: The vicissitudes of being caliente in touristic Cuba. Civilisations 62(1-2):181-97.

- 2014 Revisiting hosts and guests: Ethnographic insights on touristic encounters from Cuba. Journal of Tourism Challenges and Trends 6(2):39-62.

- 2015. Breadwinners, sex machines and romantic lovers: Entangling masculinities, moralities, and pragmatic concerns in touristic Cuba. Etnografica 19(2):389-411.

- 2016a. Tourism and informal encounters in Cuba. Oxford and New York: Berghahn Books.

- 2016b. Ethnography, mutuality, and the utopia of love and friendship in touristic Cuba. Journal of the Anthropological Society of Oxford 8(1):143-67.

Simoni, V., and S. McCabe. 2008. From ethnographers to tourists and back again: On positioning issues in the anthropology of tourism. Civilisations 57(1-2):173-89.

Stout, N. 2008. Feminists, queers and critics: Debating the Cuban sex trade. Lournal of Latin American Studies 40:721-42.

- 2014. After love: Queer intimacy and erotic economies in post-Soviet Cuba. Durham, NC: Duke University Press.

Turner, L., and J. Ash. 1975. The golden hordes: International tourism and the pleasure periphery. London: Constable.

Wonders, N. A., and R. Michalowski. 2001. Bodies, borders, and sex tourism in a globalized world: A tale of two cities - Amsterdam and Havana. Social Problems 48(4):545-71.

Wood, R. 1980. International tourism and cultural change in Southeast Asia. Economic Development and Cultural Chanoe 28(3):561-81. 